\section{ISTRAŽIVANJE DUGOG TRAJANJA (O PRIJEVODU KNJIGE M. BAHTINA NA HRVATSKI JEZIK)}

Mihail M. Bahtin, Problemi poetike Dostojevskoga. Prevele Zdenka Matek Šmit i Eugenija Ćuto. Zadar: Sveučilište u Zadru. 2020. 263 str.

"Što znači biti 'kompetentan čitatelj' Bahtina? To znači čuti dijalog, vjerojatno čak i prepoznati najvažnije glasove utjelovljene u njemu, ali to treba biti dijalog u kojem nijedan glas nije počinio 'ni najmanje nasilje'. To se može činiti paradoksalnim, posebice imamo li na umu Bahtinovu sklonost vojničkim me-

184 taforama. U njegovim se tekstovima riječi uvijek natječu, vode se bitke, osvaja se i gubi teritorij." (Emerson 1984: xxxvii)

Nećemo puno pretjerati sa sljedećom paralelom: koliko je Fedor M. Dostoevskij važan za razvoj ruskog i svjetskog romana, toliko je Mihail M. Bahtin važan za razvoj suvremene filologije, sociolingvistike i suvremene kulturologije. Međutim, dok je stvaralaštvo Dostoevskoga u cijelosti prevedeno na hrvatski jezik, Bahtinovi su radovi, osim kratkoga teksta "O metodologiji humanističkih znanosti" ("O metodologii gumanitarnyh nauk", Quorum, 2009), nepoznavateljima ruskoga jezika do sada bili dostupni na srodnim ili drugim jezicima - od srpskog ${ }^{1}$ do engleskog. Filozofsko shvaćanje i čovjeka i kulture

${ }^{1}$ Prijevod Bahtinove studije o Dostoevskom prvi je put objavljen u izdavačkoj kući Nolit 1967. Druga su izdanja uslijedila 2000. (beogradski Zepter) i 2019. (novosadska Akademska knjiga). kao složenoga dijaloga, koje Bahtin izvodi iz čitanja proze Dostoevskoga, izvršilo je revolucionaran utjecaj na sociolingvistiku te položilo temelje suvremenoj kulturologiji. S tom knjigom pojam polifonije/ mnogoglasja na široka vrata ulazi u filologiju te se iz nje širi u druga područja proučavanja u humanističkim i društvenim znanstvenim disciplinama: od rodnih studija do psihoanalize. Bahtin je, kako i sam ističe u kratkom predgovoru studiji o Dostoevskom, ruskome piscu pristupio prvenstveno kao umjetniku, a ne kao filozofu i/ili publicistu. U tom je smislu izvršio značajan i u ono vrijeme pionirski zaokret u proučavanju Dostoevskog od "filozofske kritike s početka stoljeća prema strukturno-idejnom proučavanju" (Bočarov, 437). Čitajući Dostoevskog, doista se moramo stalno podsjećati da su njegova djela - bez obzira na niz drugih u njima prisutnih dimenzija - romani, pripovijesti i novele. A ako se složimo s tvrdnjom Deana Dude da je roman, povijesno promatrano, uvijek "eksces i stoga zahtijeva pristup koji može tu ekscesnost iznijeti na vidjelo, a to ujedno znači da tako osmišljena ideja romana uočava dinamiku u kojoj roman preosmišljava čitavo književno polje" (Duda 2019: 14), tada inovativna Bahtinova čitanja Dostoevskoga, u velikom dijelu posvećena upravo romanu, ne samo da su izmijenila polje proučavanja književnosti nego se mogu promatrati i kao intervencije u samo književno polje. To je, uostalom, naslutio i Wayne C. Booth ističući 1984: "Ako je Bahtin u pravu, velika većina onoga na što su zapadnjački proučavatelji književnosti trošili vrijeme ili je pogrešno, ili trivijalno, ili oboje" (Booth 1984: xxv).

Knjiga pod naslovom Problemi stvaralaštva Dostoevskog (Problemy tvorčestva Dostoevskogo) objavljena je prvi put davne 1929. Potom je većinom zaboravljenu studiju "ponovno otkrila" skupina mla- 
dih entuzijastičnih stručnjaka s Moskovskog sveučilišta 1950-ih, pa je knjiga pod naslovom Problemi poetike Dostoevskog, preuređena i dopunjena, objavljena 1963. godine. ${ }^{2}$ Poznato je da je Bahtin na studiji o Dostoevskom radio od barem 1921. godine (Emerson 1984: xxix; Bočarov 2019: 621) te postoje dokazi da je bila pripremljena za tisak već 1922 . Osim što su i 1910-e i 1920-e vrlo dinamične iz perspektive književnog $\mathrm{i}$ umjetničkog stvaralaštva (književni i umjetnički pravci brzo se rađaju i posustaju u polemici i dijalogu jedni s drugima), posebice su dvadesete godine vrijeme intenzivnog proučavanja poetike Dostoevskog: od Jurija Tynjanova i Borisa Ėngel'gardta do Leonida Grossmana. U godini objavljivanja knjige, 1929, Bahtin je uhićen zbog sudjelovanja u radu neslužbene crkve. Zbog lošeg je zdravlja izbjegao progon u logor te je poslan u Kazahstan. Njegova su druga istraživanja, o autoru u junaku, stvaralaštvu Rabelaisa i narodnoj kulturi srednjovjekovlja, govornim žanrovima, filozofiji postupka te (moguće) o marksizmu i filozofiji jezika i frojdizmu, objavljivana tek od 60-ih i 70-ih godina, kada postaje i svjetski poznat: danas se smatra jednim od vodećih ruskih i svjetskih filologa i filozofa kulture.

Knjiga Problemi poetike Dostoerskog implicitna je teorija dijaloga. U središtu je Bahtinove filozofske koncepcije dijalogizam koji pretpostavlja nužnost dviju svijesti/spoznaja u ostvarivanju sobytija bytija ("događaj bivstvovanja", u doslovnome prijevodu). Iz tog je principa proizašao niz inovativnih koncepcija, od polifonije i karnevaleskne narodno-smjehovne (rus. narodno-smehovaja) kulture do dvoglasne riječi, odnosno riječi koja likom. se i svjesno i nesvjesno formira pod utjecajem svoje usmjerenosti na tuđu riječ ("riječ s osvrtom", Bahtin 2020: 201; rus. slovo s ogljadkoj, Bahtin 1972: 201). Taj je pojam u srži Bahtinovih shvaćanja i proučavanja ne samo književnosti nego i kulture te filozofije čovjeka općenito: čovjekov život i njegova spoznaja imaju dijalošku prirodu. Promišljajući čovjeka, Bahtin polazi od intersubjektivnosti i interindividualnosti ("ja sam ispred sebe" - rus. ja nabožus' vperedi sebja, "još me nema" - rus. menja ěše net, "sav sam u budućnosti” - rus. ja ves' v buduščm), što je ključno epistemološko polazište za razumijevanje i Bahtinova poimanja suštine književnoga djela kao komunikacijskog čina specifične prirode. Kako primjećuje Wayne C. Booth: "čitajući Bahtina, važnije je pitanje kako čitamo ili kako procjenjujemo fikciju. Pokušaj da se u toj knjizi autorski glas transcendira nije priručna diskusija o tehničkim sredstvima kojima se ostvaruju odredeni umjetnički efekti; to je prije cjeloživotno istraživanje u apsolutna pitanja o cijelom umijeću mišljenja o značenju ljudskoga života" (Booth 1984: xxiv). U stvaralaštvu Dostoevskog, tog "najnenaivnijeg od svih pisaca" (Bočarov 2019: 613), ${ }^{3}$ Bahtin nalazi ostvarenje polifonijskoga ideala jer su njegova djela temeljena na supostojanju ravnopravnih spoznaja: "Dostojevski, slično geteovskom Prometeju, ne stvara

${ }^{3} \mathrm{U}$ tekstu "O jednom razgovoru i oko njega" Sergej Bočarov govori o jednom od susreta s Bahtinom u lipnju 1970. u staračkome domu u Grivnu te ističe sljedeće: "Pred Dostojevskom svi ispadaju naivni: Gogolj je u Odabranim mjestima jako naivan, Tolstoj se divio svemu i svačemu, Dostojevski se nije ničemu divio te je samo tražio. To je bila jedna od najomiljenijih Bahtinovih tema i često se pojavljivala u našim razgovorima" (Bočarov 2019: 613). 
bezglasne robove (poput Zeusa), nego slobodne ljude sposobne stati usporedo sa svojim tvorcem, ne suglašavati se $s$ njim i čak ustajati protiv njega" (Bahtin 2020: 10). Kao što je već dobro poznato, polifonijski se roman (ta nova romaneskna vrsta prema Bahtinovu shvaćanju) temelji na drukčijim principima oblikovanja karaktera od tradicionalnog monološkog romana, pa ruski istraživač polifonijskim romanima Dostoevskoga suprotstavlja Tolstojev monološki roman. Dok Tolstoj kao autoritativan pisac "rukovodi" sviješću svojih junaka ${ }^{4}$ (što nipošto nije neosporiva Bahtinova pretpostavka), junaci Dostoevskoga formiraju se s pozicije pogleda junaka "izvana" na svoju samospoznaju i svijest: "Utvrditi tude 'ja' ne kao objekt, nego kao drugi subjekt - takvo je načelo pogleda na svijet Dostojevskoga" (ibid.: 13). Glas autora u tom smislu nije u poziciji prednosti ili nadmoći nad glasovima romanesknih junaka - i autor s junakom stupa u dijaloške odnose, što se posebno jasno očituje kada autor sam ulazi u dijaloške odnose s junakom (primjerice kao lik kroničara u Bjesovima). U polifonijskom romanu autor kao da govori s junakom, a ne - kao u monološkom romanu - o njemu/njoj, pri čemu ne dominiraju ni junak ni autor, niti se oni neutraliziraju. ${ }^{5}$

4 “Tu postoji samo jedan subjekt koji spoznaje, svi su ostali objekti njegove spoznaje. Ovdje nije moguć dijaloški odnos autora prema junacima, zato nema 'velikog dijaloga' u kojem bi ravnopravno sudjelovali junaci i autor, postoje samo kompozicijski izraženi unutar autorova vidokruga objektni dijalozi između likova" (Bahtin 2020: 72).

${ }^{5}$ Razliku između polifonijskog i monološkog romana rječito je opisao već spomenuti Wayne C. Booth uspoređujući ih na temelju centripetalne, odnosno centrifugalne sile koja dominira jednim (monološkim), odnosno dru-
Aspekt odsutnosti neutralizacije osobito se jasno nadaje u dijaloškom principu narodno-smjehovne kulture karnevala, o čemu Bahtin piše i u recenziranoj studiji i u svojoj drugoj značajnoj studiji, Stvaralaštvo Françoisa Rabelaisa i narodna kultura srednjega vijeka $i$ renesanse (Tvorčestvo Fransua Rable i narodnaja kul'tura srednevekov'ja i Renessansa, 1965). U središtu je njegove koncepcije karnevala, koji se promatra kao "neuobičajeno gibak oblik umjetničke vizije, svojevrstan heuristički princip koji omogućuje otkrivanje novog, dosad nevidenog" (Bahtin 2020: 162), pojam ambivalentnosti, pri čemu se - kao i u odnosu autora i junaka u književnome djelu - binarne opozicije poput svoj/tuđ, smrt/rođenje i smijeh/ ozbiljnost ne neutraliziraju, nego kreiraju specifičnu složenu "dvoglasnu riječ" koja samo na formalnoj razini pripada osobi koja govori, no suštinski je čine dva glasa u dijaloškim odnosima.

Osim dijaloga, koji, kao što sam spomenula, premrežava svaki aspekt

gim (polifonijskim) romanom (Booth 1984: xxi-xxii). Spomenimo da u svojoj studiji o Dostoevskom Bahtin primjećuje da su brojni istraživači opusa Dostoevskoga primijetili razliku u odnosu na druge ruske pisce njegove ili ranijih generacija. Vjačeslav Ivanov je, primjerice, primijetio da u osnovi tragične katastrofe u stvaralaštvu Dostoevskoga "uvijek leži solipsistička razdvojenost junakove svijesti, njegova zatvorenost u vlastitom svijetu" (Bahtin 2020: 14); Sergej Askol'dov primijetio je unutarnju samostalnost junaka Dostoevskoga (ibid.: 16), Leonid Grossman istaknuo je "isključivo značenje dijaloga u njegovu stvaralaštvu" (ibid.: 20), a Boris Èngel'gardt - da kod Dostoevskoga ideja nije načelo, nego predmet prikazivanja (ibid:: 28). Pritom su svi ti istraživači - $\mathrm{i}$ ovdje stupa Bahtinova kritika - monologizirali dijaloško načelo u djelima Dostoevskoga, tj. uključili su ga u monološki formuliran autorski pogled na svijet. 
ljudske djelatnosti, Bahtinova je novina i u tvrdnji da književno djelo valja promatrati (i) u društvenom kontekstu njegova funkcioniranja. Pritom je, da ne bude zabune, uvijek riječ o tzv. imanentnoj društvenosti, odnosno komunikativnosti književnoga djela. $U$ tom je aspektu Bahtin polemizirao s u to vrijeme vrlo dinamičnom i utjecajnom ruskom formalnom školom: za Bahtina je književno djelo uvijek u neprestanom dijalogu s okruženjem, koje čine pisac, čitatelj i povijesno vrijeme. Objašnjenje da je ta društvenost djela "imanentna" nalazi se kod Bahtina u njegovu specifičnom shvaćanju forme. Ona, prema Bahtinu, izražava samog pisca. Forma takoreći "objektivizira" autorski subjektivitet. Drugim riječima, formom se, tj. odabirom umjetničkih postupaka i principom organizacije književnoga djela, taj subjektivitet, što uključuje i sustav vrijednosti, posredno izražava (i) u književnome djelu. Tu je "imanentnu društvenost" književnoga djela dobro opisao P. Medvedev ("Bahtin pod maskom") u knjizi Formalna metoda u znanosti o književnosti (Formal'nyj metod v literaturovedenii): "Stvarnost književnog prikaza, njegov razvoj u realnome vremenu društvene komunikacije i ideološko značenje prikazanog događaja prožimaju se u jedinstvu umjetničke konstrukcije, ali tu je konstrukciju nemoguće do kraja shvatiti oslanjajući se samo na uvjete njezine društvene provedbe. Naime, stvarni je razvoj djela, primjerice sižea ili kazivanja (rus. skaz), cijelo vrijeme orijentiran na publiku, te ga se ne može shvatiti izvan međuodnosa onoga koji govori i onoga koji sluša ili autora s čitateljem" (Medvedev 2002: 139).

Pojam ideologije također je jedna od okosnica Bahtinovih pristupa kulturi: ona je u književnome djelu upisana u različitim aspektima organizacije književnoga svijeta - od same činjenice imenovanja određenog junaka do pripovjednih i stilskih rješenja. Taj je aspekt "pupčane veze" književnoga djela i ideologije u Bahtinovim istraživanjima Wayne C. Booth točno opisao kao "ideološki formalizam": "Budući da ispričati priču znači izdati čistu formu, priču treba na neki način frustrirati: ostaviti neke stranice nepovezanima, dopustiti da je čitatelj uskomeša, ispričati sve po abecednom redu; nametnuti različite igre riječima i trikove s točkama gledišta, sve podsjetiti da je strukturalna zamršenost jedina legitimna korist; ponuditi eksplicitne komentare kako bi se čitatelje podsjetilo da tvojim djelima ne 'rukovode' bilo kakvi interesi samih junaka i njihovih odnosa, nego brojčani sustav ili stohastički postupci poput izmiješanih karata ili računala. No sramotna je činjenica da čim imenuješ svoje junake i dopustiš da se nešto dogodi, čitatelji će ih u okrutnoj naivnosti tretirati kao da su ljudi u ljudskim situacijama, te će svi pokušaji stvaranja čiste forme biti uzaludni. Očit neuspjeh čistog formalizma da se adekvatno obračuna s najjednostavnijom fikcijom doveo je do različitih pokušaja da se ideologija ne tretira kao skandal, nego kao zagonetka" (Booth 1984: xv). U tako zacrtanim koordinatama vrijedi promatrati i prostor u književnome djelu, o čemu je Bahtin ekstenzivno pisao i u svojim drugim studijama, primjerice u Oblicima vremena i kronotopa u romanu (Formy vremeni $i$ bronotopa $v$ romane, 1938-1939, objavljena 1975). Osim što je kronotop, kao estetska kategorija koja označava povezanost vremena i prostora (vrijeme se razvija u prostoru, a prostor se mjeri vremenom), neposredno vezan uz smisao književnoga djela, žanr i sliku čovjeka, on je i dubinski ideologičan, što vjerojatno najbolje ilustrira znamenit Svidrigajlovljev opis vječnosti: "jedna 
sobica, tolika kolika je seoska kupka, zadimljena, po svim kutovima pauci" (Dostoevskij 2008: 236).

Sve su te teme ekstenzivno elaborirane u prevedenoj Bahtinovoj studiji o stvaralaštvu Dostoevskoga, pa ona nije dobrodošao prilog samo već boljim poznavateljima Bahtinovih istraživanja, nego i čitateljima koji se s Bahtinom tek upoznaju. Premda su Bahtinove ideje i terminologija već pustile duboko i čvrsto korijenje $\mathrm{u}$ istraživanjima domaćih slavista, filologa i kulturologa, prevedena knjiga, uz nedavno objavljenu knjigu Bahtinovih radova o romanu, naslovljenu Teorija romana, ${ }^{6}$ dobro je polazište za dosad gotovo nepostojeće detaljnije bahtinološke rasprave (i) u krugu domaćih istraživača.

O Bahtinovoj inovativnosti (koja, čini se, s vremenom ne zastarijeva) govori i 188 njegov metajezik koji je pred prevoditeljice s rusistike Sveučilišta u Zadru, Zdenku Matek Šmit i Eugeniju Ćuto, stavljao niz teško rješivih izazova. Emerson je točno primijetio: "Bahtinovi neologizmi imaju drugu, ali povezanu funkciju. Čak i ako su povremeno nezgrapni, to bi moglo biti jer uobičajeni jezik Bahtinu ne nudi diskurzivne kategorije koje mu treba-

${ }^{6}$ Knjiga Teorija romana, objavljena u Edicijama Božičević, sastoji se od sljedećih Bahtinovih studija o romanu: Riječ u romanu (1934-1935), Uz Bildungsroman (1936-1938), Oblici vremena i kronotopa $u$ romanu (1937-1938/1939), Iz pretpovijesti romaneskne riječi (1940) i Roman kao književni žanr (1941). Osim prijevoda jednog od zapisa Sergeja Bočarova, bliskog Bahtinova suradnika, predgovor izdanju napisao je Dean Duda (Pitanje romana $i$ Babtinov odgovor). Premda se u knjizi navodi da je objavljena 2019, čitateljima je postala dostupna u rujnu 2020. U toj sam knjizi, uz Ivu Alebića, sudjelovala kao prevoditeljica. ju. Zbog toga on stvara nove svjetove, a starima daje novu funkciju" (Emerson 1984: xxxv). Primjerice, govori se o jednoakcentnosti (rus. odnoakcentnost', Bahtin 1972: 149) "autorskog prikazivanja i junakovih govora i proživljavanja" (Bahtin 2020: 82), odnosno o "idejnoj jednoakcentnosti djela" (ibid: 81), o načelu "ideološke jednotonosti" (ibid.: 80; rus. odnotonnost', Bahtin 1972: 138) ili o "ovanjštinjujućim i definitivno završenim" autorovim odrednicama (Bahtin 2020: 16; rus. obyčno ovnešajuščie $i$ zaveršajuščie avtorskie opredelenija, Bahtin 1972: 19). ${ }^{7}$ Prevođenje Bahtina izuzetno je zahtjevan posao i zbog specifičnih bahtinovskih složenica poput "sustavno-monološki" (Bahtin 2020: 12; rus. sistemno-monologičeskij, Bahtin 1972: 11), "objektivno-umjetnički" (Bahtin 2020: 16; rus. ob"ektivno-budožestvennyj, Bahtin 1972: 19), "skriveno-polemički" (Bahtin 2020: 201; rus. skryto-polemičeskij, Bahtin 1972:360), "umirujuće-samozadovoljan" (Bahtin 2020: 204; rus. spokojno-samodovol'nyj, Bahtin 1972: 365) ili pak kada Bahtin kaže da je Dostoevskij "najmanje bio posjedovno-kućno-sobno-stambeno-obiteljski pisac" (Bahtin 2020: 165; rus. usadebno-domašne-komnatno-kvartirno-semejnyj, Bahtin 1972: 292). I dok su prevoditeljice nalazile kvalitetna $\mathrm{i}$ razumna rješenja u izazovima vezanima uz specifičan znanstveni stil, pa je riječ o pouzdanom prijevodu koji je zadržao dovoljno bahtinovskog znanstvenog duha, istaknula bih da takvom izdanju,

${ }^{7}$ Spomenimo da je posljednji navedeni primjer, neologizam ovnešajuščj, jedini istaknut u zasebnoj bilješci jer su prevoditeljice taj neologizam, inače vrlo važan u bahtinologiji, odlučile prevesti vlastitim neologizmom. Od ostalih popularnih bahtinoloških neologizama istaknula bih raznorečie, vnenabodimost', inojazyčie i raznomirnost'. 
posebice jer je riječ o prvom prijevodu Bahtinove cjelovite studije na hrvatski jezik, nedostaje detaljno kazalo imena i pojmova, kao i popratna riječ (predgovor ili pogovor) koja bi ponudila i znanstveno-povijesni kontekst u kojem je studija nastajala i njezino kritičko čitanje temeljeno na danas već postojećim ekstenzivnim istraživanjima Bahtinove studije i u Rusiji i izvan nje.

Bahtinovo je čitanje Dostoevskoga, barem sudeći po sjećanjima njegovih bliskih suradnika, u znatnoj mjeri bilo pod utjecajem stroge samocenzure. $\mathrm{Na}$ pitanje Sergeja Bočarova: što je "izopačeno u vašoj knjizi o Dostojevskom?" (Bočarov, 437) Bahtin je odgovorio: "Pa što je s vama, zar bih je ja mogao tako napisati? $\mathrm{Pa}$ tamo sam formu otrgnuo od glavnog. Nisam mogao otvoreno govoriti o glavnim pitanjima. [...] Filozofskim, o onome što je Dostojevskog mučilo čitav život - postojanje Boga. $\mathrm{Pa}$ morao sam tamo čitavo vrijeme okolišati - vrludati tamo-amo. Morao sam se cijelo vrijeme savladavati. Čim bi mi neka misao pala na pamet, već sam je trebao zaustavljati" (ibid.). Bahtinovu knjigu o Dostoevskom stoga treba čitati kao u velikoj mjeri nedovršenu knjigu treba čitati retke, ali i sve ono izmedu njih. Konačno, na Bočarovljevo pitanje: “A knjiga o Dostojevskom?” Bahtin je u travnju 1974. odgovorio: "Odlučio sam početi. I na kraju nisam ni znao da će se taj početak pokazati kao kraj" (Bočarov, 439). Ta je "nedovršiva završenost" suptilno upisana u stil Bahtinova istraživačkog pisma, koje - bez obzira na to čita li se u originalu na ruskome jeziku ili u prijevodu - zahtijeva čitatelja koji u ponavljanjima, variranjima, sintaktičkim vratolomijama i nerijetkim nedosljednostima vidi, izmedu ostalog, i mimetički odraz tragova koji su, kao posljedica dubokog uranjanja u djela Dostoevskoga, oblikovali Bahtinov znanstveni jezik. Naime, načelo Dostoevskoga sukladno s kojim se "živi čovjek ne smije pretvarati u bezglasan objekt izvanjski prikazane i zaokružene spoznaje. Čovjek uvijek ima u sebi nešto što samo on može u sebi otkriti u slobodnom činu samospoznaje i riječi, a što se ne da definirati izvana i izvan očiju" (Bahtin 2000: 60) obilježje je i Bahtinova znanstvenog stila. Njegovi znanstveni radovi doista djeluju, kako navodi i Caryl Emerson, kao da su bili namijenjeni prije svega dinamičnom slušanju, tijekom kojega se teze nalaze u perpetualnom procesu nastajanja, a ne čitanju (xxxiii). To se ne odnosi samo na Bahtinove teško prevodive neologizme, nego i na posebnu otvorenost znanstvenog pisma koje se može, čini mi se, dobro opisati Bahtinovim opisom poetike Dostoevskoga: kao i Dostoevskij i Bahtin, "kazavši paradoksalno, nije razmišljao mislima, nego stajalištima, svijestima, glasovima" (Bahtin 2020: 91). Čitati Bahtina znači čuti (i) te često suprotstavljene glasove. "Bahtin je osjetljiv prema autoritetu u diskurzu: tko govori, kada, kako i komu, preko koliko posrednika - i kako su te razine autoriteta prikazane u hibridnim konstrukcijama. Njegova je proza, treba dodati, često tkanje takvih hibrida. U jednoj rečenici on će reprezentirati neposredni govor, upravni govor, kvazineposredni govor, svoj vlastiti glas unutar drugih glasova i argumente svojih oponenata i suputnika" (Emerson 1984: xxxvi). Čitatelj koji će u Bahtinovim istraživanjima tražiti jasne $i$ nedvosmislene definicije i upute "kako čitati književno djelo" neće iscrpiti svu vrijednost Bahtinovih glasova - jer je njihova vrijednost upravo u nedosljednostima, nezavršenostima i unutarnjim proturječjima. Bahtin nam ne daje upute "kako čitati", nego nas prije svega uči kako nenaivno i sofisticirano misliti. 
Prikazi, "Femine erranti": biblijske žene u djelima talijanskih renesansnih umjetnica (190-197)

"Umjetnost riječi" LXIV (2020) • 1-2 • Zagreb • siječanj - lipanj

\section{LITERATURA}

Bahtin, Mihail M. 1972. Problemy poètiki Dostoevskogo. Izdanie tret'e. Moskva: Izdatel'stvo "Hudožestvennaja literatura".

Bahtin, Mihail M. 2009. "O metodologiji humanističkih znanosti”. Prevela Danijela Lugarić. U: Quorum 25, 5-6: 393-408.

Bahtin, Mihail M. 2020. Problemi poetike Dostojerskoga. Prevele Zdenka Matek Šmit i Eugenija Ćuto. Zadar: Sveučilište u Zadru.

Bočarov, Sergej G. 2019. “O jednom razgovoru i oko njega". U: Bahtin, Mihail M. Teorija romana. Preveli Ivo Alebić i Danijela Lugarić. Zagreb: Edicije Božičević: 611-650.

Booth, Wayne C. 1984. "Introduction". U: Bakhtin, Mikhail. Problems of veo Caryl Emerson. Minneapolis/ London: University of Minnesota Press: xiii-xxvii.

Dostoevskij, Fedor M. 2008. Sobranie sočinenij: Prestuplenie i nakazanie: Roman. Moskva: Mir knigi, Literatura.

Duda, Dean. 2019. "Pitanje romana i Bahtinov odgovor". U: Bahtin, Mihail M. Teorija romana. Preveli Ivo Alebić i Danijela Lugarić. Zagreb: Edicije Božičević: 11-22.

Emerson, Caryl. 1984. "Editor's Preface". U: Bakhtin, Mikhail. Problems of Dostoevsky's Poetics. Uredio i preveo Caryl Emerson. Minneapolis/ London: University of Minnesota Press: xxix-xliii.

Medvedev, Pavel S. 2002. Formal'nyj metod $v$ literaturovedenii. Moskva: Labirint.

Danijela Lugarić Vukas

\section{"FEMINE ERRANTI": BIBLIJSKE ŽENE U DJELIMA TALIJANSKIH RENESANSNIH UMJETNICA}

Francesca Maria Gabrielli, Evine kćeri: žene o biblijskim ženama u talijanskoj renesansi. Zagreb: Disput. 2019. 217. str.

"Re-vizija - čin kojim gledamo unatrag, vidimo novim očima, ulazimo u stari tekst iz nove kritičke perspektive - za nas je mnogo više od poglavlja u kulturnoj povijesti: re-vizija je čin preživljavanja”, piše Adrienne Rich u članku "When We Dead Awaken: Writing as Re-Vision" (1972). Isti se citat - nipošto ne slučajno - pojavljuje kao moto uvodnoga poglavlja kojim Francesca Maria Gabrielli otvara knjigu Evine kćeri: Žene o biblijskim ženama u talijanskoj renesansi. Feministička je to studija posvećena verbalnoj i vizualnoj reinterpretaciji ženskih biblijskih likova u djelima pet talijanskih autorica (Isotte Nogarole, Lucrezije Tornabuoni de' Medici, Vittorije Colonne, Arcangele Tarabotti i Artemisije Gentileschi) koje djeluju u široko shvaćenom razdoblju renesanse, od 15 . stoljeća do prve polovice 17. stoljeća. Renesansne autorice Svetome pismu prilaze iz perspektive "hermeneutike re-vizije" 